\title{
白と黒の絹織物の織り組織の違いが視覚に及ぼす影響
}

\author{
文化女子大学 鄭秋子・成瀬 信子

\section{Effects of Difference in Weave on the Visual Evaluation of White Silk Fabrics and Black Ones}

\section{Chooja Jung and Nobuko Naruse}

Faculty of Home Economics, Bunka Women's University, 3-22-1, Yoyogi, Sibuya-ku, Tokyo, 155 Japan

\begin{abstract}
The effectiveness of two conventional techniques to evaluate the surface qualities of silk fabrics, the ranking method and the paired-comparison method, was studied. The mutual correlation and the effects of the differences in color and weave on the accuracy of the evaluation were analyzed. Eight types of silk fabrics were compared; each type had the same material, weave density, and count of the weaving yarns, but each had a differ. ent weave. They were visually evaluated as to luster, quality of texture, and attractiveness for two cases: in one. the sample were white, and in the other, they were dyed black. The obtained data showed that the correlation between the two techniques was high. For both sample colors, the paired-comparison method was somewhat superior to the other in the accuracy of determination. For some of the items compared (luster and attractiveness), evaluation was appreciably affected by color, but for others (surface roughness and thickness), this was not so.
\end{abstract}

(Received December 7, 1994)

\section{1. 腥 言}

轿維製品が，消費者に十分に評価されるためには力学 的, 光学的測定による物理的特性だけでなく，人間の感 覚を計器とした官能的特性を加え棇合的な評価としてと らえて検討することが大切である。従来，織物の材質感 に関して, 力学的特性, 光学的特性, 官能的特性との関 係を統計的手法を用いて解析した研究は多く，語洒の方 法も種々試みられている。

ここ数年間の研究動向としては，手触りと結びづけた 風合い㑚定が確立して来ている。風合いには，広義の風 合いと狭義の風合いがあり，前者は触覚と視覚による布 の総合評価, 後者は布の力学的特性を触覚だけで官能的 にとらえたものとして考えられている[1]。しかし，風 合いの良し悪しは単に触賞だけでなく，必ず視感覚が伴 って働くものと考えられる。この視覚の影響は, Binns [2-4]やBrown [5]，西松ら[6]の研究を見ると明らかで ある。

Binnsは，羊毛の篠の違いを視覚的には瀻維の細さを，

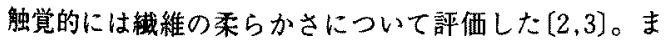
た綿織物，羊毛織物扔よび綿と羊毛の混紡織物を試料と
して，品質の良さについて視覚と触覚の二方向から順位 法上り，被唡者を䄉維業界に従事している尃門家と成人 および学生達の非専門家グループに分けて評価した論文 で，視覚評価の方が触覚評価の場合よりもより正確であ ることを報告している(4)。しかし彼は被検者グループ 間の一致度究明にだけ重点を置いているため, 触覚に対 する視覚の影響については検討がなされていない。

また，Brownは材質の違うメリヤスのバルキー性に ついて，大学生や大学職貝を被検者として䘽覚だけの評 価と触覚だけの評価，視覚と触覚による評価で官能検查 を行った結果を出し，触覚に視覚も加えて垀価すると視 覚が，触覚に影響されることを報告している[5]。 同様に，西松らはパイル織物の風合い評価における視 覚の影響の有意性について, 䄉維製品検查に従事する専 門家グループと被服学を尃攻する女子短大生の消費者グ ルーブを被検者として, 視覚と触覚による総合評価, 視 覚だけによる評価，触覚だけによる評価を行った結果， 視覚と触覚による総合評価および視覚だけによる評価が 触覚だけによる評価より正確であったことを報告した [6]。 しかし,これらの研究はいずれも，材質, 織り系の太 
さ，色が違う試験布に扔ける比較であり，今回用いた試 験布のように，材質，織り系の太さ，系密度などの構成 条件を一定にし，組織だけを変えた試験布についての官 能検查に関する研究報告は見当たらない。

そこで，本研究では，基本的に視覚評価をとらえるた めに同一の䅌素材で，組䅧だけを变之た試料を用いて， 順位法と一対比較法の二つの手法で官能検查を行い，組 織の違いに対する視覚評価の有意性と二手法間の違いに ついて検討した。

\section{2. 方 法}

\section{1 試 料}

光学的に色が買なると光の反射光量が変わるので，無 彩色の白と黑について検討を行うことにした。試料は， 表 1 に示すように組織以外の構成要因をすべて一定にし， 組織を 8 租織に変えて織った日と黒の絹織物を用いた。

8 組織の違いでは, 交錯点の一番少ない朱子織物は最 も厚く，交錯点の一番多い平織物は薄い傾向を示す。ま た，同一組織内では，織系で染色を行った黑い織物の方 が白い穖物よりやや厚い傾向である。

Table 1 Details of Sample Fabrics

\begin{tabular}{|c|c|c|c|}
\hline \multicolumn{2}{|c|}{$\begin{array}{l}\text { Material } \\
\text { Yarn count }(D) \\
\text { Density of Yarn }\end{array}$} & \multicolumn{2}{|c|}{$\begin{array}{l}\text { Silk } 100 \% \\
210 \times 9 \\
28 \times 22(\text { number } / \mathrm{cm})\end{array}$} \\
\hline Textile weave & $\begin{array}{l}\text { Color of yarn } \\
\text { Warp } \times \text { Weft }\end{array}$ & $\begin{array}{c}\text { Thickness } \\
\text { (mm) }\end{array}$ & $\begin{array}{l}\text { Apparent } \\
\text { specific } \\
\text { gravity }\end{array}$ \\
\hline 1. Plain & $\begin{array}{l}\mathrm{W} \times \mathrm{W} \\
\mathrm{BL} \times \mathrm{BL}\end{array}$ & $\begin{array}{l}0.19 \\
0.20\end{array}$ & $\begin{array}{l}0.44 \\
0.50 \\
\end{array}$ \\
\hline 2. Warp rib & $\begin{array}{l}W \times W \\
B L \times B L\end{array}$ & $\begin{array}{l}0.26 \\
0.28\end{array}$ & $\begin{array}{l}0.31 \\
0.35\end{array}$ \\
\hline 3. Weft rib & $\begin{array}{l}W \times W \\
B L \times B L\end{array}$ & $\begin{array}{l}0.25 \\
0.26\end{array}$ & $\begin{array}{l}0.33 \\
0.36\end{array}$ \\
\hline 4. Basket & $\begin{array}{l}W \times W \\
B L \times B L\end{array}$ & $\begin{array}{l}0.23 \\
0.23\end{array}$ & $\begin{array}{l}0.36 \\
0.39\end{array}$ \\
\hline 5. $1 / 3$ twill & $\begin{array}{l}\mathrm{W} \times W \\
\mathrm{BL} \times \mathrm{BL}\end{array}$ & $\begin{array}{l}0.25 \\
0.26\end{array}$ & $\begin{array}{l}0.33 \\
0.36\end{array}$ \\
\hline 6. $2 / 2$ twill & $\begin{array}{r}W \times W \\
B L \times B L\end{array}$ & $\begin{array}{l}0.23 \\
0.24\end{array}$ & $\begin{array}{l}0.35 \\
0.38\end{array}$ \\
\hline 7. $4 / 4$ twill & $\begin{array}{l}W \times W \\
B L \times B L\end{array}$ & $\begin{array}{l}0.28 \\
0.29\end{array}$ & $\begin{array}{l}0.29 \\
0.31\end{array}$ \\
\hline 8. Warp satin & $\begin{array}{c}W \times W \\
B L \times B L\end{array}$ & $\begin{array}{l}0.30 \\
0.30\end{array}$ & $\begin{array}{l}0.27 \\
0.30\end{array}$ \\
\hline
\end{tabular}

\section{2 官能模查の手法}

官能検查の手法としては, 順位法と一対比較法の二つ の手法により行った。試験布は8組織の試料をそれぞれ 長さ10 cm, 幅 $6 \mathrm{~cm}$ の大きさにたて系方向とよこ亲方 向の 2 万向を別々に裁ち，N9.60台紙を各試料の裹僋 に当て作製した。官能検査の試料の組み合わせは，たて
糸方向とよこ系方向を別々に 8 組織を組み合わせた。検 查は，北憂の自然光下で，女子大生30名を被験者として 行った。官能量としては，光沢感に関するつやの大きさ (量的)，つやの良さ（質的），色に関する明るさ(明 度)，白さ (白い䅌織物)，黒さ(黒い縜織物)，表面性 状を表わす厚み感，なめらかさ，表面の粗さ，消費者の 好み感を表わす好き，扔よび絹織物なので総合評洒とし て品の良さを加え，一つの試料ダループに対する宫能量 は9項目である。

\subsection{1 舜価方法}

(1)順位法は，各特性值の評価が大きい方を1とする。 (2)一対比較法は Scheffe の方法の変形 3 である中屋の 変法（順序效果のない場合）〔7]を用いて，個人間の主 效果のばらつきは誤差に含めて分析した。評価は 5 段階 法である。

なお，順位法と一对比較法の二つの手法に対し，同一 被検者がすべての試料について評值した。

\section{3. 䊅果および考察}

\section{1 主効果の官能}

\section{1 .1 評侕に对する有意性検定}

順位法は，一致性の係数（W）を用いて，その秸果を 表 2 中に示した。表 2 に示されているように, 白い租織 物の場合は，好き，品の良さの官能量が危険率 $5 \%$ で有 意となり，他の官能量に対しては危険率 $1 \%$ の高水準で 有意となった。黑い編織物の場合は，つゃの良さと明る さには一致性が㮣められなかったが，二つの官能量を除 いた他の官能量に対しては，危険率 $1 \%$ の高水準で有意 となり，30人の被検者の評価点相互にかなり一致性があ ったと判断される。

一方，一対比較法は，分散分析法に上る有意差検定と 信頼区間を求め検討した。その結果を表 3 中に示したが， 白，黑の絹織物ともに危険率 $1 \%$ 以上の高水準で有意の 差が認められている。

\section{1 .2 判定結果}

\section{(1)順位法による判定結果}

30 人の被検者の各評価值の平均を表 2 に示した。

ここで，もしすべての被検者が同一に順位づけた場合、 信頼度の程度を示す一致性の係数（W）は1になるはず である。しかし被検者個人個人の好みや主観に応じて評 価するので，まったく同じ結果が出ることは有り得ない。 従って一致性の係数の程度をもって検討ができる。

表 2 中に示されている一致性の係数 (W) 加分加万 ように，8組織の試料に对する9つの官能量のうち，好 み感を表わす好き，品の良さの官能量に対する一致性の 係数が，白い綃織物のたて系方向，よこ系方向，黑い絹 
Table 2 Visual Evaluation Values Obtained by the Ranking Method

\begin{tabular}{c|c|c|c|c|c|c|c|c|l}
\hline $\begin{array}{c}\text { W } \times W \\
\text { Warp Direction }\end{array}$ & Plain & $\begin{array}{c}\text { Warp } \\
\text { rib }\end{array}$ & $\begin{array}{c}\text { Weft } \\
\text { rib }\end{array}$ & Basket & $\begin{array}{c}1 / 3 \\
\text { twill }\end{array}$ & $\begin{array}{c}2 / 2 \\
\text { twill }\end{array}$ & $\begin{array}{c}4 / 4 \\
\text { twill }\end{array}$ & $\begin{array}{c}\text { Warp } \\
\text { satin }\end{array}$ & W \\
\hline Quantity of luster & 7.93 & 5.30 & 6.00 & 3.00 & 6.20 & 4.43 & 1.80 & 1.33 & $0.884 * *$ \\
\hline Quality of luster & 7.17 & 5.23 & 5.50 & 3.13 & 6.07 & 4.07 & 2.47 & 2.37 & $0.520 * *$ \\
\hline Brightness & 7.13 & 5.93 & 5.43 & 3.20 & 6.87 & 4.07 & 2.03 & 1.33 & $0.796 * *$ \\
\hline Whiteness & 6.73 & 6.13 & 5.10 & 3.90 & 6.53 & 3.67 & 2.43 & 1.50 & $0.630 * *$ \\
\hline Smoothness & 2.87 & 4.67 & 3.63 & 6.10 & 3.97 & 3.57 & 6.50 & 4.70 & $0.266 * *$ \\
\hline Roughness of surface & 7.80 & 4.53 & 6.23 & 2.43 & 5.20 & 5.13 & 1.93 & 2.73 & $0.684 * *$ \\
\hline Thickness & 8.00 & 5.33 & 6.23 & 2.80 & 5.20 & 4.93 & 1.13 & 2.37 & $0.842 * *$ \\
\hline Liking & 5.93 & 5.07 & 4.57 & 4.30 & 3.90 & 3.07 & 4.13 & 5.03 & $0.125 *$ \\
\hline Fineness & 5.73 & 4.80 & 4.43 & 4.73 & 3.63 & 3.10 & 4.47 & 5.10 & $0.112 *$ \\
\hline
\end{tabular}

\begin{tabular}{c|c|c|c|c|c|c|c|c|c}
\hline $\begin{array}{c}\text { W } \times W \\
\text { Weft Direction }\end{array}$ & Plain & $\begin{array}{c}\text { Warp } \\
\text { rib }\end{array}$ & $\begin{array}{c}\text { Weft } \\
\text { rib }\end{array}$ & Basket & $\begin{array}{c}1 / 3 \\
\text { twill }\end{array}$ & $\begin{array}{c}2 / 2 \\
\text { twill }\end{array}$ & $\begin{array}{c}4 / 4 \\
\text { twill }\end{array}$ & $\begin{array}{l}\text { Warp } \\
\text { satin }\end{array}$ & W \\
\hline Quantity of luster & 7.97 & 4.80 & 6.77 & 3.00 & 3.33 & 5.60 & 1.27 & 3.27 & $0.810 * *$ \\
\hline Quality of luster & 7.30 & 4.53 & 6.27 & 3.27 & 3.53 & 4.87 & 1.87 & 4.37 & $0.488 * *$ \\
\hline Brightness & 6.00 & 5.50 & 7.10 & 3.23 & 3.23 & 5.30 & 1.40 & 4.23 & $0.560 * *$ \\
\hline Whiteness & 3.00 & 6.07 & 6.90 & 4.50 & 3.07 & 4.97 & 2.47 & 5.03 & $0.373 * *$ \\
\hline Smoothness & 2.73 & 5.10 & 3.67 & 5.77 & 3.37 & 3.67 & 5.83 & 5.87 & $0.271 * *$ \\
\hline Roughness of surface & 7.80 & 4.37 & 6.43 & 2.57 & 5.07 & 5.70 & 1.53 & 2.53 & $0.781 * *$ \\
\hline Thickness & 8.00 & 4.20 & 6.07 & 2.77 & 5.23 & 5.90 & 1.13 & 2.70 & $0.830 * *$ \\
\hline Liking & 5.47 & 5.10 & 4.60 & 4.17 & 3.10 & 3.40 & 4.13 & 6.03 & $0.168 *$ \\
\hline Fineness & 5.70 & 5.20 & 4.27 & 4.03 & 3.47 & 3.23 & 4.37 & 5.73 & $0.152 *$ \\
\hline
\end{tabular}

\begin{tabular}{c|c|c|c|c|c|c|c|c|c}
\hline $\begin{array}{c}\text { BL } \times \mathrm{BL} \\
\text { Warp Direction }\end{array}$ & Plain & $\begin{array}{c}\text { Warp } \\
\text { rib }\end{array}$ & $\begin{array}{c}\text { Weft } \\
\text { rib }\end{array}$ & Basket & $\begin{array}{c}1 / 3 \\
\text { twill }\end{array}$ & $\begin{array}{c}2 / 2 \\
\text { twill }\end{array}$ & $\begin{array}{c}4 / 4 \\
\text { twill }\end{array}$ & $\begin{array}{c}\text { Warp } \\
\text { satin }\end{array}$ & W \\
\hline Quantity of luster & 5.87 & 5.43 & 5.37 & 3.60 & 5.53 & 4.70 & 2.50 & 3.00 & $0.277 * *$ \\
\hline Quality of luster & 5.43 & 4.87 & 5.50 & 4.47 & 4.53 & 3.77 & 3.23 & 4.20 & 0.100 \\
\hline Brightness & 4.93 & 5.40 & 4.87 & 4.07 & 5.20 & 4.50 & 3.43 & 3.60 & 0.089 \\
\hline Blackness & 6.63 & 4.20 & 5.17 & 4.80 & 2.30 & 4.20 & 3.60 & 5.10 & $0.268 * *$ \\
\hline Smoothness & 2.30 & 4.17 & 3.20 & 6.67 & 4.20 & 3.87 & 6.97 & 4.63 & $0.426 * *$ \\
\hline Roughness of surface & 7.87 & 5.00 & 6.20 & 2.27 & 5.13 & 5.00 & 1.47 & 3.07 & $0.746 * *$ \\
\hline Thickness & 8.00 & 5.60 & 6.23 & 2.60 & 4.40 & 4.90 & 1.27 & 3.00 & $0.784 * *$ \\
\hline Liking & 5.40 & 4.50 & 4.50 & 5.70 & 3.03 & 2.80 & 4.73 & 5.33 & $0.191 *$ \\
\hline Fineness & 5.07 & 4.53 & 4.17 & 6.37 & 3.10 & 3.37 & 4.50 & 4.90 & $0.174 *$ \\
\hline
\end{tabular}

\begin{tabular}{c|c|c|c|c|c|c|c|c|c}
\hline $\begin{array}{c}\text { BLXBL } \\
\text { Weft Direction }\end{array}$ & Plain & $\begin{array}{c}\text { Warp } \\
\text { rib }\end{array}$ & $\begin{array}{c}\text { Weft } \\
\text { rib }\end{array}$ & Basket & $\begin{array}{c}1 / 3 \\
\text { twill }\end{array}$ & $\begin{array}{c}2 / 2 \\
\text { twill }\end{array}$ & $\begin{array}{c}4 / 4 \\
\text { twill }\end{array}$ & $\begin{array}{l}\text { Warp } \\
\text { satin }\end{array}$ & W \\
\hline Quantity of luster & 5.90 & 4.80 & 5.37 & 3.17 & 5.20 & 5.30 & 2.20 & 4.07 & $0.266 * *$ \\
\hline Quality of luster & 5.83 & 4.63 & 4.57 & 3.90 & 4.30 & 4.43 & 3.10 & 5.23 & $0.111 *$ \\
\hline Brightness & 4.50 & 4.20 & 4.77 & 4.03 & 4.80 & 5.13 & 3.33 & 5.23 & 0.065 \\
\hline Blackness & 7.57 & 4.27 & 4.13 & 5.13 & 5.37 & 4.73 & 3.57 & 1.23 & $0.531 * *$ \\
\hline Smoothness & 2.10 & 4.77 & 3.07 & 6.57 & 3.63 & 3.53 & 6.67 & 5.67 & $0.473 * *$ \\
\hline Roughness of surface & 7.80 & 4.60 & 6.30 & 2.47 & 5.03 & 5.57 & 1.67 & 2.57 & $0.749 * *$ \\
\hline Thickness & 7.97 & 4.73 & 5.87 & 3.00 & 5.03 & 5.63 & 1.30 & 2.47 & $0.765 * *$ \\
\hline Liking & 5.00 & 4.63 & 3.17 & 5.20 & 3.27 & 3.30 & 4.97 & 6.47 & $0.228 * *$ \\
\hline Fineness & 5.13 & 4.37 & 3.47 & 5.87 & 3.17 & 2.77 & 4.67 & 6.57 & $0.296 * *$ \\
\hline
\end{tabular}


Table 3 Visual Evaluation Values Obtained by the Paired-Comparison Method

\begin{tabular}{|c|c|c|c|c|c|c|c|c|c|c|}
\hline $\begin{array}{c}\mathrm{W} \times \mathrm{W} \\
\text { Warp Direction }\end{array}$ & Plain & $\begin{array}{c}\text { Warp } \\
\text { rib }\end{array}$ & $\begin{array}{l}\text { Weft } \\
\text { rib }\end{array}$ & Basket & $\begin{array}{l}1 / 3 \\
\text { twill }\end{array}$ & $\begin{array}{l}2 / 2 \\
\text { twill }\end{array}$ & $\begin{array}{l}/ 4 \\
\text { twill }\end{array}$ & $\begin{array}{l}\text { Warp } \\
\text { satin }\end{array}$ & Fo & $\begin{array}{c}Y \\
(5 \%)\end{array}$ \\
\hline Quantity of luster & -0.967 & -0.358 & -0.450 & 0.375 & -0.742 & -0.038 & 0.963 & 1.217 & $283.34 * *$ & 0.205 \\
\hline Quality of luster & -0.638 & -0.413 & -0.358 & 0.233 & -0.483 & 0.171 & 0.625 & 0.863 & $68.27 * *$ & 0.293 \\
\hline Brightness & -0.817 & -0.388 & -0.421 & 0.263 & -0.796 & 0.083 & 0.904 & 1.171 & $264.73 * *$ & 0.200 \\
\hline Whiteness & -0.558 & -0.392 & -0.408 & 0.129 & -0.758 & 0.208 & 0.688 & 1.092 & $182.82 * *$ & 0.209 \\
\hline Smoothness & 0.608 & -0.221 & 0.163 & -0.450 & 0.075 & 0.088 & -0.492 & 0.229 & $34.29 * *$ & 0.275 \\
\hline Roughness of surface & -1.150 & -0.117 & -0.475 & 0.567 & -0.292 & -0.125 & 1.067 & 0.525 & $182.71 * *$ & 0.225 \\
\hline Thickness & -1.067 & -0.167 & -0.283 & 0.508 & -0.325 & -0.192 & 1.050 & 0.475 & $199.33 * *$ & 0.201 \\
\hline Liking & -0.142 & -0.313 & 0.046 & -0.063 & 0.054 & 0.346 & 0.058 & 0.013 & $7.95 * *$ & 0.292 \\
\hline Fineness & -0.021 & -0.250 & 0.071 & -0.146 & 0.092 & 0.404 & -0.104 & -0.046 & $9.69 * *$ & 0.277 \\
\hline $\begin{array}{c}\mathrm{W} \times \mathrm{W} \\
\text { Weft Direction }\end{array}$ & Plain & $\begin{array}{l}\text { Warp } \\
\text { rib }\end{array}$ & $\begin{array}{c}\text { Weft } \\
\text { rib }\end{array}$ & Basket & $\begin{array}{l}1 / 3 \\
\text { twill } \\
\end{array}$ & $\begin{array}{l}2 / 2 \\
\text { twill } \\
\end{array}$ & $\begin{array}{r}4 / 4 \\
\text { twill } \\
\end{array}$ & $\begin{array}{l}\text { Warp } \\
\text { satin }\end{array}$ & Fo & $\begin{array}{c}Y \\
(5 \%) \\
\end{array}$ \\
\hline Quantity of luster & -1.021 & -0.125 & -0.654 & 0.542 & 0.317 & -0.250 & 1.033 & 0.158 & $159.22 * *$ & 0.228 \\
\hline Quality of luster & -0.792 & -0.079 & -0.413 & 0.333 & 0.400 & 0.004 & 0.696 & -0.150 & $63.61 * *$ & 0.260 \\
\hline Brightness & -0.717 & -0.192 & -0.804 & 0.475 & 0.421 & -0.200 & 0.942 & 0.075 & $145.90 * *$ & 0.217 \\
\hline Whit & 0.254 & -0.317 & -0.821 & -0.038 & 0.438 & -0.079 & 0.596 & -0.033 & $70.64 * *$ & 0.231 \\
\hline Smooth & 0.550 & -0.046 & 0.133 & -0.379 & 0.171 & 0.213 & -0.471 & -0.171 & $27.68 * *$ & 0.279 \\
\hline Roughness of surface & -1.163 & 0.008 & -0.550 & 0.521 & -0.192 & -0.296 & 1.025 & 0.646 & $204.88 * *$ & 0.216 \\
\hline Thickness & -1.242 & -0.025 & -0.342 & 0.554 & -0.121 & -0.154 & 0.913 & 0.417 & $205.46 * *$ & 0.199 \\
\hline Liking & -0.183 & -0.063 & -0.225 & 0.079 & 0.350 & 0.267 & 0.083 & -0.308 & $13.78 * *$ & 0.277 \\
\hline Fineness & -0.225 & -0.129 & -0.038 & -0.042 & 0.400 & 0.383 & -0.004 & -0.346 & $19.72 * *$ & 0.262 \\
\hline $\begin{array}{c}\mathrm{BL} \times \mathrm{BL} \\
\text { Warp Direction }\end{array}$ & Plain & $\begin{array}{c}\text { Warp } \\
\text { rib }\end{array}$ & $\begin{array}{c}\text { Weft } \\
\text { rib }\end{array}$ & Basket & $\begin{array}{c}1 / 3 \\
\text { twill } \\
-0320\end{array}$ & $\begin{array}{l}2 / 2 \\
\text { twill } \\
\end{array}$ & $\begin{array}{l}4 / 4 \\
\text { twill } \\
\end{array}$ & $\begin{array}{l}\text { Warp } \\
\text { satin }\end{array}$ & Fo & $\begin{array}{c}Y \\
(5 \%) \\
0274\end{array}$ \\
\hline Quantity of luster & -0.371 & -0.233 & -0.321 & 0.138 & -0.329 & 0.021 & 0.629 & 0.467 & $35.51 * *$ & 0.274 \\
\hline Quality of luster & -0.283 & -0.013 & -0.250 & -0.183 & 0.100 & 0.183 & 0.268 & 0.179 & $9.85 * *$ & 0.298 \\
\hline Brightness & -0.225 & -0.088 & -0.242 & 0.104 & -0.346 & 0.025 & 0.446 & 0.325 & $20.54 * *$ & 0.270 \\
\hline Blackness & -0.571 & 0.146 & -0.038 & -0.225 & 0.825 & 0.167 & 0.150 & -0.451 & $64.52 * *$ & 0.237 \\
\hline Smoothness & 0.771 & -0.033 & 0.233 & -0.654 & 0.242 & 0.113 & -0.608 & -0.063 & $64.07 * *$ & 0.254 \\
\hline Roughness of surface & -1.163 & -0.158 & -0.479 & 0.688 & -0.246 & -0.138 & 1.079 & 0.417 & $207.79 * *$ & 0.214 \\
\hline Thickness & -1.192 & -0.108 & -0.363 & 0.542 & -0.067 & -0.138 & 1.025 & 0.300 & $190.70 * *$ & 0.207 \\
\hline Liking & -0.154 & 0.075 & -0.071 & -0.442 & 0.567 & 0.317 & -0.067 & -0.225 & $25.55 * *$ & 0.274 \\
\hline Fineness & 0.054 & 0.021 & -0.104 & -0.571 & 0.558 & 0.325 & -0.129 & -0.154 & $32.55 * *$ & 0.258 \\
\hline $\begin{array}{c}\mathrm{BL} \times \mathrm{BL} \\
\text { Weft Direction } \\
\end{array}$ & Plain & $\begin{array}{c}\text { Warp } \\
\text { rib }\end{array}$ & $\begin{array}{l}\text { Weft } \\
\text { rib }\end{array}$ & Basket & $\begin{array}{l}1 / 3 \\
\text { twill }\end{array}$ & $\begin{array}{c}2 / 2 \\
\text { twill }\end{array}$ & $\begin{array}{l}4 / 4 \\
\text { twill }\end{array}$ & $\begin{array}{l}\text { Warp } \\
\text { satin }\end{array}$ & Fo & $\begin{array}{c}Y \\
(5 \%) \\
\end{array}$ \\
\hline Quantity of luster & -0.183 & -0.146 & -0.296 & 0.192 & 0.050 & -0.142 & 0.613 & -0.088 & $20.79 * *$ & 0.276 \\
\hline Quality of luster & -0.254 & -0.096 & -0.008 & -0.075 & 0.267 & 0.179 & 0.388 & -0.400 & $19.32 * *$ & 0.263 \\
\hline Brightness & 0.025 & -0.154 & -0.258 & 0.171 & 0.108 & -0.054 & 0.446 & -0.283 & $15.30 * *$ & 0.271 \\
\hline Blackness & -0.846 & 0.133 & -0.058 & -0.125 & -0.100 & 0.000 & 0.129 & 0.867 & $60.65 * *$ & 0.262 \\
\hline Smoothness & 0.842 & -0.029 & 0.350 & -0.513 & 0.142 & 0.179 & -0.567 & -0.404 & $76.59 * *$ & 0.240 \\
\hline Roughness of surface & -1.096 & -0.058 & -0.529 & 0.546 & -0.179 & -0.283 & 0.996 & 0.604 & $202.11 * *$ & 0.209 \\
\hline Thickness & -1.146 & -0.042 & -0.358 & 0.346 & -0.050 & -0.208 & 0.921 & 0.538 & $223.00 * *$ & 0.183 \\
\hline & -0.133 & 0.063 & 0.321 & -0.196 & 0.308 & 0.354 & -0.175 & -0.542 & $29.94 * *$ & 0.253 \\
\hline Fineness & -0.100 & -0.088 & 0.367 & -0.354 & 0.346 & 0.417 & -0.071 & -0.517 & $40.78 * *$ & 0.237 \\
\hline
\end{tabular}


織物のたて糸方向ともに低く，特に黒い綃織物の場合は, つゃの良さ，明るさの官能量に对する一致性の係数が低 い攧向である。

また，白い網織物をたて系方向に沿って見た場合は， つや感に関寸る官能量に対し，8組織のうち朱子織物に 一番つや感大の 1 番, 平織物にはつや感最小の 8 番の順 位が与えられ，その間を $4 / 4$ 斜文織，2/2斜子織， $2 / 2$ 斜 文織，経嘼織，緯畧織，1/3斜文織の順が位置している。 表面性状を表わす表面の粗さ，厚み感の官能量に対して は $4 / 4$ 斜文織物に 1 番の順位が, 平織物には 8 番の順位 が与えられ，比較的に交錯点の少ない織物は表面が粗く, 厚いと見ている傾向であり，これらの官能量とつゃ感や 明るさ，白さには織系の浮きの長さが大きく影響してい る。このことは，よこ系方向に沿って見た場合の結果と 比較してみると明らかである。一方，黒い絹織物の場合 は，つやの良さ、明るさの官能量には一致性が認められ なかったが、この二つの官能量を除いた他の官能量に対 しては，一致性の保数が白い絹織物に比較して低いもの もあるが，その順位の結果が白い綟織物の場合とほとん
ど変わっていないのがわかる。

\section{(2)一対比較法による判定結果}

順位法と同様, 30 人の被検者が 8 試料の 28 組の組み合 わせを対にして比較した場合の官能量の推定值と分散比， 信頼区間を求め表 3 に示した。表 3 に示されているよう に,いずれの場合についても危険率 $1 \%$ 以上の高水準で 有意の差が認められ，つゃ感や色に関する官能量に対し ては，8組織の違いが順位法で示された順位と同じ傾向 を示し，白と黒の色違い加らると，黑い絹織物よりも 白い絹織物の方が分散比が大きく，8試料間の差をより よく見分けている傾向である。しかし，表面の粗さや厚 み感の官能量に対しては，白い綟織物，黑い絹織物とも に分散比が大きく，表 3 中に示したヤードスティック

（Y） $5 \%$ 危険率は比較的小さい傾向を示すと同時に, たて糸方向に沿って見た場合よりは，よこ系方向に沿っ て見た場合が 8 試料間の差を大きく見分け，表面性状を 示す官能量は組織上方向性による影響が大きいが，色の 影響を大きく受けないことが顕著に示された。

一方，好み感に関する好き，品の良さの官能量に対し

Table 4 Correlation among Respective Visual Evaluation Values Obtained by the Ranking Method and the Paired. Comparison Method

\begin{tabular}{|c|c|c|c|c|c|c|c|c|c|c|c|c|c|c|c|c|c|c|c|c|}
\hline \multicolumn{2}{|l|}{ Color of yarn } & \multicolumn{9}{|c|}{$W \times W$} & \multicolumn{10}{|c|}{$\mathrm{BL} \times \mathrm{BL}$} \\
\hline \multicolumn{2}{|l|}{ Direction } & \multicolumn{9}{|c|}{ Weft } & \multicolumn{10}{|c|}{ Weft } \\
\hline \multicolumn{2}{|l|}{ ITEM } & 1 & 2 & 3 & 4 & 5 & 6 & 7 & 8 & 9 & 1 & 2 & 3 & 4 & 5 & 6 & 7 & 8 & 9 & \\
\hline \multirow{2}{*}{$\begin{array}{l}\text { 1. Quantity } \\
\text { of luster }\end{array}$} & $\mathrm{R}$ & & $* *$ & $* *$ & & $*$ & $* *$ & $* *$ & & & & $*$ & & & $*$ & $* *$ & $* *$ & & & \multirow{2}{*}{$\begin{array}{l}\text { 1. Quantity } \\
\text { of luster }\end{array}$} \\
\hline & $\mathrm{P}$ & & $* *$ & $* *$ & & $* *$ & $*$ & $* *$ & & & $V$ & & $* *$ & & & $*$ & & & & \\
\hline \multirow{2}{*}{$\begin{array}{l}\text { 2. Quality } \\
\text { of luster }\end{array}$} & $\mathrm{R}$ & $* *$ & & $* *$ & & & $* *$ & $* *$ & & & $*$ & & & & & & & & & \multirow{2}{*}{$\begin{array}{l}\text { 2. Quality } \\
\text { of luster }\end{array}$} \\
\hline & $\mathrm{P}$ & $* *$ & & $* *$ & & & $*$ & $*$ & & & & & & & & & & & & \\
\hline \multirow[t]{2}{*}{ 3. Brightness } & $\mathrm{R}$ & $* *$ & $* *$ & & & & $*$ & $*$ & & & $* *$ & & & & & & & & & \multirow[t]{2}{*}{ 3. Brightness } \\
\hline & $\mathrm{P}$ & $* *$ & $* *$ & 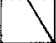 & & * & $*$ & $*$ & & & $* *$ & & & & & & & & & \\
\hline \multirow[t]{2}{*}{ 4. Whiteness } & $R$ & $* *$ & $* *$ & $* *$ & & & & & & & & & & & & & & & & \multirow[t]{2}{*}{ 4. Blackness } \\
\hline & $\mathrm{P}$ & $* *$ & $* *$ & $* *$ & & & & & & & & & & & & & $*$ & & & \\
\hline \multirow[t]{2}{*}{ 5. Smoothness } & $\mathrm{R}$ & $*$ & * & & & & $* *$ & $* *$ & & & $*$ & & & & & $* *$ & $* *$ & & & \multirow[t]{2}{*}{ 5. Smoothness } \\
\hline & $\mathrm{P}$ & & & & & & $*$ & $* *$ & & & $*$ & & & & & $* *$ & $* *$ & & & \\
\hline \multirow{2}{*}{$\begin{array}{l}\text { 6. Roughness } \\
\text { of surface }\end{array}$} & $\mathrm{R}$ & $* *$ & $* *$ & $*$ & $*$ & $* *$ & & $* *$ & & & $* *$ & $*$ & $*$ & & $* *$ & & $* *$ & & & \multirow{2}{*}{$\begin{array}{l}\text { 6. Roughness } \\
\text { of surface }\end{array}$} \\
\hline & $\mathrm{P}$ & $* *$ & $* *$ & $* *$ & $*$ & * & & $*$ & & & $* *$ & & $*$ & & $* *$ & & $* *$ & & & \\
\hline \multirow[t]{2}{*}{ 7. Thickness } & $\mathrm{R}$ & $* *$ & $* *$ & $* *$ & $*$ & $* *$ & $* *$ & & & & $* *$ & $*$ & $*$ & & $* *$ & ***. & & & & \multirow[t]{2}{*}{ 7. Thickness } \\
\hline & $\mathrm{P}$ & $* *$ & $*$ & $* *$ & $*$ & $*$ & $* *$ & & & & $*$ & & $*$ & & $* *$ & $* *$ & & & & \\
\hline \multirow[t]{2}{*}{ 8. Liking } & $\mathrm{R}$ & & & & & & & & & $* *$ & & & & & & & & & $* *$ & \multirow{2}{*}{ 8. Liking } \\
\hline & $\mathrm{P}$ & & & & & & & & & $* *$ & & & & $*$ & & & & & $* *$ & \\
\hline \multirow[t]{2}{*}{ 9. Fineness } & $\mathrm{R}$ & & & & & & & & $* *$ & & & & & & & & & $* *$ & & \multirow[t]{2}{*}{ 9. Fineness } \\
\hline & $\mathrm{P}$ & & & & & & & & ** & & & & & & & & & $* *$ & & \\
\hline \multicolumn{2}{|l|}{ Direction } & \multicolumn{9}{|c|}{ Warp } & \multicolumn{9}{|c|}{ Warp } & \\
\hline
\end{tabular}

$R$ : The ranking method $\mathrm{P}$ : The paired-comparison method

$* * 1 \%$ level of significance

$* 5 \%$ level of significance 
Table 5 Regression Analysis between the Ranking Method and the Paired-Comparison Method

\begin{tabular}{c|c|c|c|c|c|c||c|c|c|c|c|c}
\hline Color of yarn & \multicolumn{9}{|c||}{ W } & \multicolumn{6}{c}{ BL $\times \mathrm{BL}$} \\
\hline & \multicolumn{3}{|c|}{ Warp direction } & \multicolumn{3}{|c|}{ Weft direction } & \multicolumn{3}{|c|}{ Warp direction } & \multicolumn{3}{c}{ Weft direction } \\
\hline & $\mathrm{a}$ & $\mathrm{b}$ & $\mathrm{r}$ & $\mathrm{a}$ & $\mathrm{b}$ & $\mathrm{r}$ & $\mathrm{a}$ & $\mathrm{b}$ & $\mathrm{r}$ & $\mathrm{a}$ & $\mathrm{b}$ & $\mathrm{r}$ \\
\hline Quantity of luster & 1.52 & -0.34 & $-0.985 * *$ & 1.33 & -0.30 & $-0.989 * *$ & 1.32 & -0.29 & $-0.984 * *$ & 0.91 & -0.20 & $-0.884 * *$ \\
\hline Quality of luster & 1.36 & -0.30 & $-0.964 * *$ & 1.22 & -0.27 & $-0.976 *$ & 1.10 & -0.24 & $-0.885 * *$ & 1.16 & -0.26 & $-0.793 *$ \\
\hline Brightness & 1.51 & -0.34 & $-0.990 * *$ & 1.45 & -0.32 & $-0.983 * *$ & 1.58 & -0.35 & $-0.916 * *$ & 1.35 & -0.30 & $-0.777 *$ \\
\hline Whiteness & 1.47 & -0.33 & $-0.978 * *$ & 1.24 & -0.28 & $-0.969 * *$ & 1.45 & -0.32 & $-0.934 * *$ & 1.15 & -0.26 & $-0.978 * *$ \\
\hline Smoothness & 1.19 & -0.26 & $-0.902 * *$ & 1.11 & -0.25 & $-0.939 * *$ & 1.27 & -0.28 & $-0.968 * *$ & 1.26 & -0.28 & $-0.980 * *$ \\
\hline Roughness of surface & 1.52 & -0.34 & $-0.985 * *$ & 1.14 & -0.23 & $-0.896 * *$ & 1.50 & -0.33 & $-0.996 * *$ & 1.44 & -0.32 & $-0.995 * *$ \\
\hline Thickness & 1.28 & -0.28 & $-0.982 * *$ & 1.29 & -0.29 & $-0.972 * *$ & 1.33 & -0.30 & $-0.978 * *$ & 1.30 & -0.29 & $-0.989 * *$ \\
\hline Liking & 0.78 & -0.17 & $-0.791 *$ & 0.99 & -0.22 & $-0.933 * *$ & 1.26 & -0.28 & $-0.940 * *$ & 1.21 & -0.27 & $-0.989 * *$ \\
\hline Fineness & 0.77 & -0.17 & -0.710 & 1.16 & -0.26 & $-0.927 * *$ & 1.36 & -0.30 & $-0.914 * *$ & 1.15 & -0.26 & $-0.981 * *$ \\
\hline
\end{tabular}

a, b: Regression constants $r$ : Coefficient of correlation $* * 1 \%$ level of significance $* 5 \%$ level of significance

ては，黑い絹織物の方が白い絹織物より分散比が，扔よ そ2 倍以上に大きく，8試料間の差をやや大きく見分け ていることがわかる。

\section{2 官能睘の相関分析による結果}

順位法による官能量間の相関性と一対比較法による官 能量間の相関性を表 4 に示す。

表 4 中の R は順位法，Pは一対比較法を示し，表の左 側は白い絹織物，右側が黒い䅌織物の場合で，斜線の左 下はたて糸方向に沿って見た場合，右上はよこ系方向に 沿って見た場合の結果である。

先ず白い絹織物をたて糸方向に沿って見た場合は，表 4 に示されているように，つやの大きさ，つやの良さ， 明るさ，白さ，なめらかさ，表面の粗さ，厚み感の官能 量に対しては各官能量問の相関性が高いが，これらの官 能量と好き，品の良さの官能量とは 2 手法ともに相関性 が見られていない。しかし，好み感に対する好きと品の 良さの官能量間には高い相関性を示している。

これに対し，よこ系方向に沿って見た場合は，白さの 官能量がつやの大きさ，つやの良さ，明るさの官能量と の相関性が見られていないのが，たて系方向に沿って見 た場合と異なるところである。

一方，黑い組織物の場合は，たて系方向に沿って見た 場合，よこ糸方向に沿って見た場合ともに黒さと他の官 能量との相関性が順位法では全く見られなかったが，一 対比較法では，たて系方向に沿って見た場合の好きの官 能量との相関性が見られた。従って，光学的な理論でも 白は黒より光沢が大きく，しかも浮系の方向に沿って見 た場合は，浮采と直角方向加見た場合上り光沢が大き いことはよく知られていることであり，視覚的な評価か らも白さとつゃの大きさとの相関は高く，黑さとつゃの
大きさとは相関がないことが同一条件の綟織物でも顕著 に示され，色と方向性が大きな要因であることが明らか であった。

\section{3 順位法と一対比較法の回喂分析による結果}

順位法と一対比較法の手法の違いを比較するため，各 官能量ごとに順位法による各官能量の平均值を（X）と し，一対比較法による官能量の推定値を（Y）として，

最小自乗法による直線回帰式（ $\mathrm{Y}=\mathrm{a}+\mathrm{b} X)$ を求めた。 その結果の $\mathrm{a} ， \mathrm{~b}$ と相関保数 $\mathrm{r}$ を表 5 に示す。

表 5 より白い綃織物をたて系方向に沿って見た場合， 品の良さの官能量には，相関性が認められなかったが, 他の官能量についてはいずれの場合も信頼区間95\%から $99 \%$ の範囲内で相関性が認められ，光沢感や表面性状を 示す官能量については評伍基準が充分客観性を持つもの であることが確かめられたので，一例として，つやの大 きさの官能量を図1に示した。

图1より，白い絹織物は 8 組織間の分布が大きい㑯向 であるが，黒い絹織物は 8 組織間の分布がかなり接近し ている傾向を示し，回臣直楾の傾きからつやの大きさに 対する評価は黒よりも白の方が見分けやすいことが顕著 に示された。このことは，光学的な反射特性との対応 〔8〕でも明らかであった。

\section{4. 䊅 論}

白と黒の 8 組織の絹織物について，順位法と一対比較 法の 2 手法により視覚的な官能検查を行った結果, 次の ことが言えた。

1）直線回帰分析により，順位法と一対比較法の2 手法 間の相関性は高いことが認められたが，検定の結果，一 対比較法は主観的尺度がずれても，相対的判定をするの 

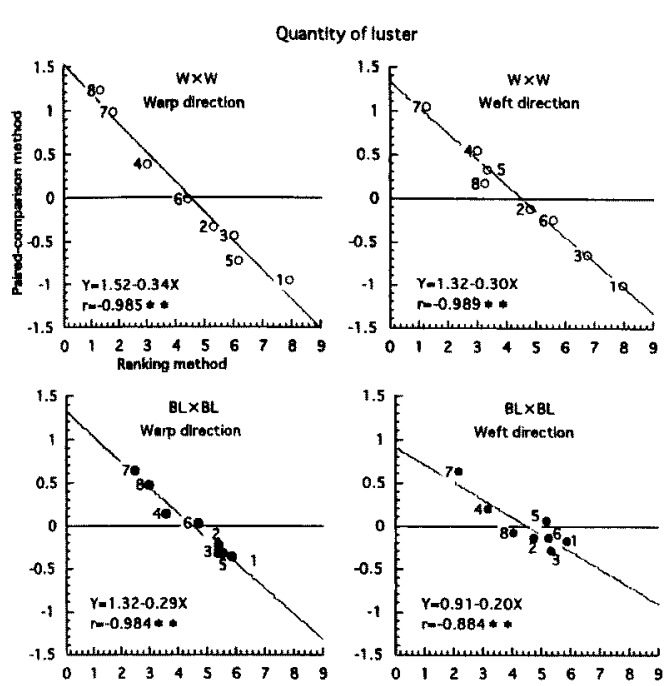

Fig. 1 Relationship between the ranking method and the paired-comparison method, estimated by the regres sion analysis.

で，安定した結果を精度高く得ることができるが，順位 法は一度に多くの試料の差を一水準上の差として捉える ので，検査法としては容易であるがいくらか精度が落ち
ることが示された。

2）光沢感を表わす官能量に対しては，同一条件であっ ても，白い絹織物の方が黑い絹織物より試料間の差を大 きく見分けているが，好み感に対する官能量に対しては 黒い絹織物の方が，よりよく見分けている傾向が見られ 白と黒の色の影響が大きいことが示された。

3）表面性状を表わす表面の粗さ，厚み感の官能量に対 しては，色の影響はなく，組織と方向性が大きいことが 示された。

よって，この報告では，織物構成を一定にして，組織 のみを変えた 8 組織に対する感覚的な評価が白い綃織物 と黒い綟織物ではどの程度何が異なるのかを明らかに示 すことができた。

\section{文献}

1. 小林茂雄, 紻学誌, 26, p.88 (1973).

2. H. Binns, J. Text. Inst. 25. T331 (1934).

3. H. Binns, J. Text. Inst, 29, T117 (1938).

4. H. Binns, J. Text. Inst, 17, T615 (1926).

5. Bronw. Text, Res. J, 39, 395 (1969).

6. 西松豊典, 酒井哲也, 䄉学誌, 41, T396 (1985).

7. 日科技連官能検査委員会編，官能検查ハンドブック， (1965).

8. 矨秋子, 成瀬信子, 瀻学誌, 51，234（1995)。 